\title{
"I do not mind immigrants; it is immigration that bothers me." The inconsistency of immigration attitudes in Europe
}

\author{
DITA ČERMÁKOVÁ, YANA LEONTIYEVA
}

Institute of Sociology of the Czech Academy of Sciences, Prague, Czechia; e-mail: dita.cermakova@soc.cas.cz, yana.leontiyeva@soc.cas.cz

ABSTRACT Using the European Social Survey data we studied migration attitudes in 19 European countries, including Czechia. We introduced and tested the assumption about the bi-dimensional nature of migration attitudes, where personalized attitudes towards immigrants as individuals might differ from the generalised attitudes toward immigration as a phenomenon. The results of our analysis have provided arguments to suggest that one person may in fact has rather positive attitudes towards individual immigrants (in term of willingness to accept them in closer contacts in everyday life) and at the same time express reservations about immigration as a phenomenon (be more sceptical about the positive outcomes of international migration). The article also contributes to the discussion about the country context, which seems to have an important effect on migration attitudes. People in CEE countries tend to express considerably greater social distancing from individual immigrants than people in those European countries with relatively longer immigration experience. But when it comes to attitudes towards immigration as a phenomenon, here the feelings are rather reserved all across Europe.

KEY WORDS immigration - attitudes towards immigrants in Europe - personalized and general attitudes - ethnic competition framework - social distance - European Social Survey

ČERMÁKOVÁ, D., LEONTIYEVA, Y. (2017): “I do not mind immigrants; it is immigration that bothers me." The inconsistency of immigration attitudes in Europe. Geografie, 122, 4, 500-525.

Received September 2017, accepted October 2017.

(C) Česká geografická společnost, z. s., 2017 


\section{Introduction}

This article was prepared in the light of the ongoing debate in many European countries concerning the so called "migration crisis" and the response of the European Union to the influx of refugees from war zones and politically unstable countries. The migration debate often oscillates between two points: (1) being humane to people in need and (2) protecting the right of a state to choose whom to accept on its territory. The pro-migration advocates tend to use the first mentioned point referring to universal human values and the need to understand, appreciate, show tolerance and protect the welfare of all people. Their opponents often justify their anti-migration beliefs referring to conservative values and the need to address the potential threat of immigration for the wellbeing of the receiving society, its culture, democracy, political power etc.

In this article we suggest that when analysing migration attitudes in different countries it could be useful to think of them as two dimensional. Our main research question is to study the difference between attitudes towards individual immigrants and those towards international migration as a social phenomenon. To be more exact, we presume that it is not uncommon for a person to express more tolerant attitudes towards individual immigrants and at the same time be more sceptical when judging the impact of international migration as a social phenomenon.

The idea of this article is to explore the difference between what we call personalized attitudes towards immigrants in different situations and more general attitudes towards migration as a phenomenon. Our research assumption is that the difference between these two types of attitudes is not necessarily an inconsistency of beliefs but rather a result of different underlying mechanisms. Earlier research showed that migration attitudes as such might be caused by individual characteristics of the respondents (demographic, socio-economic status, contacts with migrants, values etc.) and contextual conditions (economic situation in the country, migration rate and character, political and media discourse etc.) (Strabac, Listhaug 2008; Pettigrew, Tropp 2006). In the analysis presented in this article we measure and compare the effect of individual and contextual factors on the two (interrelated but in our view still different) types of attitudes.

Our theoretical explanations are focused mostly (but not exclusively) on two concepts: the concept of social distance and the ethnic competition theory. We expect that each of these theoretical arguments explains rather different dimensions of migration attitudes. Although social distance is explained as a measure of how close or distant people feel towards members of other (not only ethnic) groups (Wark, Galliher 2007), we believe that this concept is more focused on personal contacts, ties and interactions between individuals than on the self-identification with the own group. In contrast to that, the ethnic competition approach works 
more with the self-identification and it is based on explaining interaction between two major groups defined as the majority ("us") versus migrants ("them"). The ethnic competition approach and theories based on it basically argue that migration is predominantly about the competition between these two mentioned groups for (limited) resources and assets in the host society (Savelkoul et al. 2010; Schlueter, Scheepers 2010; Forbes 2004).

Both approaches provide rather different explanations for the effect of numbers of immigrants in the country on the overall attitudes towards them. According to the social distance theory, an increasing number of immigrants in the host society is connected with less social distancing from them. This is in line with so called contact theory, suggesting that a higher immigration rate results in a higher probability of interpersonal contacts between the majority population and immigrants and, therefore, better attitudes towards the latter (Pettigrew 1998). On the contrary, according to the ethnic competition theory, a higher immigration rate might be connected with a greater competition for resources and a greater threat to the host society resulting in more negative migration attitudes (Dixon 2006).

The existence of two distinct perspectives in migration attitudes was actually noted by Brewer and Miller (1984) more than three decades ago, when they claimed that one should not see immigrants as just members of the out-group but that attitudes towards immigrants should be personalized. Authors noted that personalization involves direct self-other comparison across categories. They suggest that such a "decategorization" of immigrants may increase intergroup acceptance and actually help to reduce the perception of group threat and social competition (Brewer, Miller 1984).

As was already mentioned, the main research aim of this article is to explore the differences in the migration attitudes of a person, depending on whether he or she expresses attitudes towards individual immigrants or attitudes towards immigration as a phenomenon. In our analysis however we are not only trying to make an argument about the bi-dimensionality of migration attitudes but would also like to test whether intergroup contact theory is better suited to explaining the attitudes on what we call the individual level (attitudes towards migrants), while the ethnic competition explanation works better on the more generalized level when migration is judged as a phenomenon. In order to test our research hypotheses we used data from the European Social Survey (ESS round 7) module dedicated to migration and collected in 21 European countries in 2014. We ran our analysis on the international data but we are also interested in some contextual (country) explanations.

We believe that understanding the differences between the two types of migration attitudes described above could be also useful when applying a multidimensional perspective to the process of immigrants' integration in the European context. Today there seems to be a common consensus about the multidimensional 
nature of the integration process (Heckmann, Schnapper 2003). In our analysis we see some parallels between the two described dimensions of migration attitudes and what Heckmann and Schnapper (2003) called the structural and the interactive dimensions of integration. Successful structural integration of immigrants (access to economy, labour market, education, qualification system, housing market, citizenship, political community etc.) is a good prerequisite for but not necessarily a guarantee of successful social integration, such as inclusion into private relations, social interaction, friendships, mixed marriages, voluntary associations etc. As already mentioned, we expect the attitudes towards migrants as individuals and attitudes towards migration as a phenomenon to be correlated but we argue that they are not the same thing. We hope that exploring and understanding the gap between these two could help us to explain the controversy of the current migration debate in Europe.

\section{Theoretical Framework}

\subsection{Ethnic competition approaches}

The ethnic competition framework is based on two theories - group conflict theory and social identity theory (Savelkoul et al. 2010). Both theories are based on the claim that the formation of attitudes is caused by self-identification with one's own group and the identification of other out-groups (Savelkoul et al. 2010). ${ }^{1}$ Simultaneously, self-identification with the group is often connected with realizing the position of one's own group in a hierarchy of out-groups. This group hierarchy may cause competition and consequently conflicts between the groups (Semyonov et al. 2004). The conflicts are primarily economic, politic and territorial and result in perceptions of threat, prejudice and hostility (Blumer 1958 in Schlueter, Scheepers 2010). The factors that influence the perception of threat from an out-group are the out-group's relative size, spatial concentration, actual changes in size, perceived size (Savelkoul et al. 2010) and economic circumstances such as average income (Quilian 1995, 1996), unemployment rate (Scheepers, Gijsberts, Coenders 2002) and GDP (Semyonov et al. 2004).

We expect that the ethnic competition framework operates primarily at the group level. However, the perception of immigration as a threat might not only influence attitudes towards the phenomenon as such but it can also affect personalized attitudes towards immigrants (Bobo, Hutchings 1996). Negative attitudes in the host population could be explained, for example, by direct competition

1 These out-groups need not be just ethnic groups but also e.g. homosexuals, the mentally ill, economically strong/weak (Forbes 2004). 
with individual immigrants (persons coming from an out-group) on the labour market if employers abuse the differences in labour costs in order to weaken the bargaining position of the "natives" (Dixon 2006).

\subsection{Social distance attitudes}

The concept of social distance describes the degree of sympathetic understanding between individuals from different groups (Bogardus 1959 in Ouellette-Kunz et al. 2010). The concept came from the Chicago School (1920s) and created a practical psychological testing proximity between people using the Bogardus social distance scale. The scale measures people's closeness or distance toward a range of individuals in a range of personal interactions. On this scale the highest possible degree of interpersonal interaction with immigrants is accepting them in mixed marriages (marrying or accepting as close family members). Next come a range of interactions like accepting immigrants as close friends, neighbours on the same street, co-workers, and even the citizens in one's country. On the extreme end of this scale is the exclusion of non-citizen visitors in given country. For our analysis it is important that (a) this concept measures the variety of individual interactions (in which interaction an individual might feel confident with the other person), and (b) that there is a group connotation (from which groups the person is). Although measured social distance also reflects attitudes toward the whole out-group, we presume that this psychological concept speaks primarily about individual personal attitudes rather than about attitudes based on selfidentification with the group.

\subsection{Intergroup contact theory}

Personal contacts, if they are carried out under optimal conditions, ${ }^{2}$ could be a significant explanatory factor in the elimination of interethnic prejudice, intergroup tension, anxiety, and hostility and even threats (Wagner et al. 2006). There are even authors (Pettigrew, Tropp 2006; Pettigrew et al. 2011) who claim that every contact has positive outcomes regardless of the existence of optimal conditions and the nature and quality of the contact. With regard to migration attitudes, intergroup contact theory holds that a higher number of immigrants in the country means more opportunities for interpersonal contacts and therefore more positive migration attitudes in the receiving population (Wagner et al. 2006). Strabac,

2 The optimal conditions are equal status, common goals, a lack of intergroup competition and authority sanctions (Allport 1954 in Pettigrew 1979). 
Aalberg, Valenta (2014) explain that the simple presence of immigrants can bring positive outcomes in attitudes purely due to the fact that people do not want to have negative ideas about people with whom they share the same space (house, neighbourhoods, country). Nevertheless, analysis of interethnic contacts and their impact on attitudes show that the issue of interethnic contacts and encounters is more problematic and particularly that the quality, intensity and intimacy of contacts, cooperativeness and positive emotions are crucial in positive relations, particularly to experiences of migration (Islam, Hewstone 1993; Wang, Collins 2016). Forbes (2004) sees interethnic contacts as difficult cognitive and emotional mechanisms which create a different situation with different outcomes. Other conditionalities are also important: whether the participants of intercultural contacts are willing to challenge their own comfort zones and, further, whether these contacts are based on a significant investment in emotional labour (Wang, Collins 2016). Migrants are challenged by uncertainty, anxiety and a sense of distance that limits their confidence to build relationship networks beyond their communities (Wang, Collins 2016). The main criticisms of contact theory are doubts about the results of negative contacts which cause a deterioration in intergroup attitudes (Stephan, Stephan 1985 in Schulueter, Scheepers 2010; Forbes 2004).

Factors testing the contact hypothesis are the size of the out-group, the intensity, frequency and quality of contracts, and variables observing equal status, cooperative/competitive interdependence, the presence/absence of common social norms, degree of education etc. According to these variables, the contacts will exacerbate or revive intergroup ties, tending to trust/distrust. It is interesting that many studies use the number of migrants and automatically count this as the likelihood of contact, although contact may or may not occur and, furthermore, this does not say anything about its quality. The existence of interethnic contacts, their intensity and above all their quality is important for our analysis at both levels because the contacts are primarily personally based, but can influence attitudes at the group level.

Educational achievement (Coenders, Scheepers 2003; Hainmueller, Hiscox 2007) and economic status of the respondents (Facchini, Mayda 2006; Hainmueller, Hiscox 2007; Wilkes, Guppy, Farris 2008; Schneider 2008) are generally discussed as important factors predicting both, overall positive attitudes towards immigration as a phenomenon and less social distancing from immigrants. Taking into account the fact that immigrants are often clustered at the bottom of the labour market, it is logical, that lack of education and low socio-economic status of respondents are generally associated with rather negative migration attitudes due to the perceived threat as a result of the competition on the labor market. However, the literature also discusses whether those better educated respondents who happen to have certain prejudices and stereotypes towards immigrants just appear better in the survey because they tend not to declare what seem to be 
socially less acceptable attitudes. This could also contribute to both, the impact of the educational system and the effect of social desirability (Mayda 2004; Hainmueller, Hiscox 2007).

\subsection{Human values to explain attitudes}

People's attitudes are generally influenced by human values (Zich, Anýžová, eds. 2017) and migration attitudes are no exception (Davidov et al. 2008). There are a number of theories oriented towards the evaluation of human values, among the most popular of which are Hofstede's theory of values (power versus distance, individualism versus collectivism, uncertainty, masculinity versus femininity), Inglehart's theory of the division of materialist and post-materialist values, Rokeach's belief system theory, and Schwarz's Basic Human Values theory (Inglehart, Welzel, 2005; Davidov 2008). In our analysis we worked with Schwarz's Basic Human Values, because the Portrait Values Questionnaire was a part of the European Social Survey (ESS) questionnaire. Schwarz's theory (1992) describes 10 basic types of human values which are integrated into a broader value system and organised in four major groups: openness to change, conservation, self-enhancement, and self-transcendence. According to Schwarz (1992), universalism and benevolence (as a part of self-transcendence) are concerned with the welfare of others and are opposed to self-enhancement values (such as hedonism, achievement and power), which present values focusing on personal success. Conservation values (tradition, security and conformity) are held by people who respect social norms (conformity), social order (security) and customs (tradition). On the contrary, values open to change are held by people who like independent thought and action (self-direction) and novelty and change in life (stimulation). Due to the fact that immigration often brings changes in the traditions and norms of the host society, it is not surprising that people with predominantly conservative values have rather exclusionist attitudes and prefer ethnic homogenity (Davidov 2008, Vlachová 2017). Nor is it surprising that people with self-transcendent values have more positive attitudes toward immigration (Davidov 2008). Based on this, we decided to study the effect of two self-transcendence values (universalism and benevolence), and two conservation values (tradition and security) on migration attitudes in our contribution. ${ }^{3}$

3 Tests of invariance carried out by multi-group confirmatory factor analysis (MGCFA) indicated partial metric equivalence of human basic values, the independent variables are therefore appropriate for multivariate analysis (see also Anýžová 2014). 


\subsection{Towards group and individual attitudes: the research hypothesis}

Our analysis is concentrated around six main research hypotheses (some of them further elaborated) through testing which we hope to confirm and at least partly explain possible differences between the individual and the group level of immigration attitudes.

- H1: There is a difference in respondents' attitudes towards immigrants as individuals and immigration as a phenomenon influencing the receiving society.

- H2: Attitudes towards immigrants as individuals (personalized attitudes) tend to be more positive than attitudes towards immigration as a phenomenon (generalized attitudes).

- H3: Higher education and higher socio-economic status have a positive impact on migration attitudes on both levels.

- H3A: Experience with socio-economic hardships has a stronger effect on attitudes towards immigration as a phenomenon (compared to personalized migration attitudes).

- H4: Personal contacts with immigrants have a positive impact on migration attitudes on both levels.

- H4A: The effect of personal contact with immigrants is greater when it comes to attitudes towards immigrants as individuals (compared to generalized attitudes).

- H5: Human values have a significant impact on migration attitudes on both levels.

- H5A: Universalistic and benevolent human values have a positive effect on migration attitudes, while orientation toward traditionalism and security values result in more reserved migration attitudes.

- H6: The country context has a strong effect on migration attitudes even when controlled for the effect the individual characteristics (i.e. respondent's education, socioeconomic status, values and contacts with immigrants).

- H6A: The difference between personalized and generalized migration attitudes will be universal across countries.

- H6B: People in countries with longer experience of immigration are more tolerant when it comes to both personalized and generalized migration attitudes.

\section{Data and Methodology}

Our data comes from the ESS, to be exact from the seventh round of the ESS implemented in 2014-2015 (we used the second edition of the data). The migration module of the ESS provides a wide range of data including questions useful for testing the abovementioned research hypotheses in the European context. 
Tab. 1 - ESS sample size of "non-migrants" selected for further analysis in each country (2014)

\begin{tabular}{lcc}
\hline Country & $\begin{array}{c}\text { Non foreign-born respondents } \\
\text { selected for the analyses }\end{array}$ & $\begin{array}{c}\text { Share of the total } \\
\text { country sample (\%) }\end{array}$ \\
\hline Belgium & 1,542 & 87 \\
Czechia & 2,102 & 98 \\
Germany & 2,745 & 90 \\
Denmark & 1,382 & 92 \\
Estonia & 1,649 & 80 \\
Spain & 1,756 & 91 \\
Finland & 1,987 & 95 \\
France & 1,694 & 88 \\
United Kingdom & 1,950 & 86 \\
Hungary & 1,671 & 98 \\
Switzerland & 1,139 & 74 \\
Ireland & 2,075 & 87 \\
Lithuania & 2,175 & 97 \\
Netherlands & 1,736 & 90 \\
Norway & 1,267 & 88 \\
Poland & 1,598 & 99 \\
Portugal & 1,170 & 92 \\
Sweden & 1,554 & 87 \\
Slovenia & 1,124 & 92 \\
\hline Total & 32,316 & 89 \\
\hline
\end{tabular}

Source: ESS7

The original dataset contains data from 21 European countries collected from more than 40,000 respondents ${ }^{4}$. Based on our previous research we suspect that when it comes to explaining migration attitudes, the specific country context could have an even greater impact than the individual characteristics of respondents (Leontiyeva 2015). Therefore while running our multivariate analysis on the international data we also measure the effect of contextual (mostly country) indicators.

In order to analyse attitudes towards immigrants we excluded all respondents with a migrant background from our analysis ${ }^{5}$. We are aware of the possible bias applied selection may cause in cross-country analysis, meaning that we selected more cases in "new" migration countries and fewer in countries with a larger share of immigrants. Nevertheless this decision was based on the belief that attitudes of migrants to other migrants might be quite specific and significantly different from

4 Austrian data was excluded due to a serious translation error in the Austrian translations in ESS round 7 related to variables, which were used in our analyses.

5 Migration background of the respondents was identified based on their country of birth. 
the attitudes of those who do not have a direct experience of migration (Schlueter, Wagner 2008). Table 1 presents the size of the samples in different countries in the resulting ESS7 dataset used for all further analyses.

\section{Analysis of attitudes towards immigrants and immigration}

\subsection{Defining and measuring individual and group level attitudes}

There is a set of migration-related attitudinal variables available in the ESS 7 data. We were particularly interested in using indicators with similar scales and describing the attitudes towards immigrants in what we assume to be different dimensions. In our view personalised attitudes towards migrants were indicated by attitudinal questions measuring so called social distance to immigrants in terms of accepting individual immigrants in mixed marriages or as a boss ${ }^{6}$. The wording of these two questions was inspired by the Bogardus social distance scale and when it comes to the attitudes towards migrants these questions are often used in combination with a wider range of social distance indicators such as attitudes to migrants being co-workers, neighbours, spouses, etc. (Schlueter, Wagner 2008). Unfortunately this set of attitudinal questions was not used in the ESS 7 migration module, therefore we had to utilize the best available data and construct our personalized attitudes scale from two available indicators.

In addition to the questions mentioned, the ESS 7 questionnaire also included a set of six questions measuring more generalized migration attitudes and relating to the perceived threat or benefit of migration as a phenomenon 7 . Some of these

6 The following questions were used to measure the attitudes in question: "Now thinking of people who have come to live in [country] from another country who are of a different race or ethnic group from most [country] people. Using this card, please tell me how much you would mind or not mind if someone like this... D10 ... was appointed as your boss? D11 ... married a close relative of yours?" The respondents had to choose one answer on a scale from 0 "Not mind at all" to 10 "Mind a lot". For the purpose of the analyses and comparison with the set of variables described further in the text the scale was inverted, i.e. the higher score means a more tolerant attitude.

7 The following questions were used to measure the mentioned attitudes: "B32 Would you say it is generally bad or good for [country]'s economy that people come to live here from other countries? B33 Would you say that [country]'s cultural life is generally undermined or enriched by people coming to live here from other countries? B34 Is [country] made a worse or a better place to live by people coming to live here from other countries? D7 Would you say that people who come to live here generally take jobs away from workers in [country], or generally help to create new jobs? D8 Most people who come to live here work and pay taxes. They also use health and welfare services. On balance, do you think people who come here take out more than they put in or put in more than they take out? D9 Are [country]'s crime 
questions were also used by other authors in order to measure the perception of ethnic (group) threat (Schlueter, Wagner 2008; Schlueter, Scheepers 2010; Savelkoul et al. 2010). Here respondents were asked to evaluate the influence of immigrants on the host society in general and also in particular on the country's economy, cultural life and criminality, in terms of competition on the labour market and as a part of the healthcare and welfare systems. Even the wording of these questions implies that here (unlike in the previous two questions) respondents were asked to express not attitudes to specific model examples of migrants (like a boss or a relative) but rather attitudes to migrants as representatives of a certain larger group; the questions used the words like "generally" or "your country".

All eight mentioned indicators used a scale from zero to ten, with only extreme values labelled as positive or negative attitudes towards immigrants as individuals or immigration as a phenomenon. In order to standardize our measurement, we inverted the scale for the first two indicators so that 0 always means the most negative attitude (mind a lot) while ten signifies the most positive attitudes (not mind at all). Before constructing our two scales for personalized and generalized migration attitudes we ran a factor analysis to see if the extraction of two separate latent variables (scales) is justified in the data. The results showed that the model with two latent factors (two attitudinal dimensions as described above with 2 items for personalized attitudes and 6 items for generalized attitudes) fits the data better than the model with all measured variables contributing to one factor as a cumulative migration attitude.

Based on the results of confirmatory factor analysis and in order to test our research hypotheses in the next analytical step we constructed two separate indicators (further used as two dependent variables) as a mean of items associated with a given latent factor. The measured individual and group level attitudes (as cumulative indexes) were correlated and interdependent and, as was mentioned earlier, we expected some of the factors to have a universal effect on both levels. Nevertheless in our further analyses we are particularly interested in exploring and explaining the difference between the two attitudinal dimensions we extracted from the data. Before we proceeded to the regression analysis allowing us to explore the effect of different individual and contextual factors on two separate attitudinal dimensions, we decided to see if what we call personalized or individual attitudes towards migrants are really more positive than generalized attitudes towards migration as a phenomenon (what we call group attitudes). In addition,

problems made worse or better by people coming to live here from other countries?" The respondents had to choose one answer on a scale from 0 to 10. A zero score here was defined as a negative impact like "bad for the economy", "undermine cultural life", etc., while the highest score 10 was described as positive impact like "good for the economy", "cultural life enriched" and so on. 
Tab. 2 - Paired sample T-test between individual and group means in 7 round of ESS (2014)

\begin{tabular}{lcccccc}
\hline & Mean & $\begin{array}{c}\text { Std. } \\
\text { Deviation }\end{array}$ & $\begin{array}{c}\text { Std. Error } \\
\text { Mean }\end{array}$ & t & df & Sig. (2-tailed) \\
\hline Mean Individual - Mean Group & -2.57 & 2.65 & 0.02 & -169.43 & $30,375.00$ & 0.00 \\
\hline
\end{tabular}

Source: ESS7, own calculation

in line with one of our research hypotheses, we also intended to explore whether the difference is similar in different countries across Europe.

The analysis shows that while in general Europeans tended to express rather positive attitudes towards immigrants on the individual level (the mean value for the whole sample is 6.96), they expressed more reserved feelings towards immigrants on the group level (the mean value is 4.76 ). Two computed indicators of individual and group level attitudes are significantly positively correlated: the Pearson correlation coefficient is 0.406 and it is significant at the 0.01 level (2-tailed). In order to answer the question of whether the means for constructed individual and group level are significantly different we ran a paired sample T-test. The calculated statistical significance suggests that the diameters of the two levels are in fact statistically different: the significance (2-tailed) is 0.000 (Table 2). We realize that the scale for the measured indicators is not completely identical (see above for the wording of the questions used) and that the difference we found could partly be explained by altered wording of the labels for the extreme points. However, for the purpose of our analysis we assumed that the analysed data allow us to suggest that the nature of these attitudes is in fact different and that the results of analysis described above justify the usage of two transformed indicators as separate dependent variables (Social distance and Group threat).

Before proceeding to the multiple regression analyses we examined the difference between the means of constructed attitudinal variables across countries. A series of separate tests on national level for each country in the data proved to have the same results as the tests for the whole sample, meaning that the difference between two constructed indicators was statistically significant in all countries except Israel ${ }^{8}$ (see Fig. 1).

Figure 1 illustrates an interesting finding concerning the difference between the two extracted dimensions of attitudes across countries. As mentioned, in all 19

8 Israel is a specific immigration country, where only non-ethnic migrants (without a Jewish background) are considered to be immigrants. Therefore the expressed attitudes are not toward the whole migrant population but only toward foreign workers (Raijman, Semyonov 2004). Due to this fact we decided to exclude the Israel from subsequent analysis. 


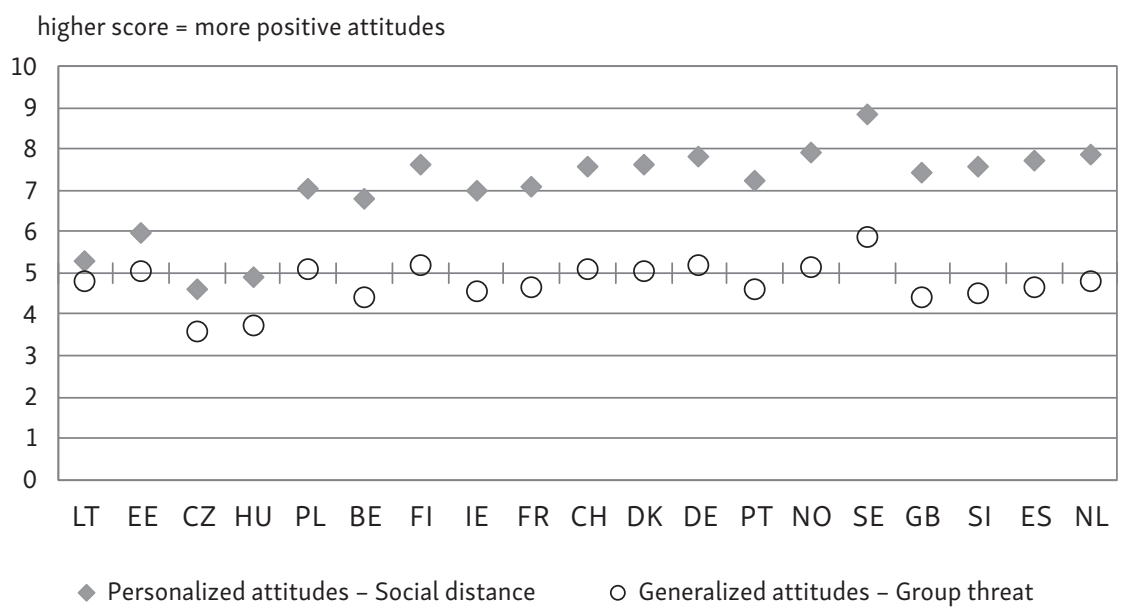

Fig. 1 - The means for constructed attitudinal indicators across countries in 7 round of ESS (2014) Source: ESS 7, own calculation.

BE - Belgium, CZ - Czechia, DE - Germany, DK - Denmark, EE - Estonia, ES - Spain, FI - Finland, FR - France, GB - United Kingdom, HU - Hungary, CH - Switzerland, IE - Ireland, IL - Israel, LT Lithuania, NL - Netherlands, NO - Norway, PL - Poland, PT - Portugal, SE - Sweden, SI - Slovenia. The Individual level attitudes were constructed from questions: "Now thinking of people who have come to live in [country] from another country who are of a different race or ethnic group from most [country] people. Using this card, please tell me how much you would mind or not mind if someone like this... D10 ... was appointed as your boss? D11 ... married a close relative of yours?" The respondents had to choose one answer on a scale from 0 "Not mind at all" to 10 "Mind a lot". The group level attitudes were constructed from questions: "B32 Would you say it is generally bad or good for [country]'s economy that people come to live here from other countries? B33 Would you say that [country]'s cultural life is generally undermined or enriched by people coming to live here from other countries? B34 Is [country] made a worse or a better place to live by people coming to live here from other countries? D7 Would you say that people who come to live here generally take jobs away from workers in [country], or generally help to create new jobs? D8 Most people who come to live here work and pay taxes. They also use health and welfare services. On balance, do you think people who come here take out more than they put in or put in more than they take out? D9 Are [country]'s crime problems made worse or better by people coming to live here from other countries?" The respondents had to choose one answer on a scale from 0 to 10.

countries (except Israel) the differences between individual and group level scores are statistically significant, however the distance between the measured indexes varies across the countries. The lowest means for both constructed indicators were found in the Czech and the Hungarian data; the respondents in Sweden score as the most tolerant on both levels. The exploratory cross-country comparison illustrated in Figure 1 suggests that in all the countries across Europe respondents tend to be more positive when it comes to their attitudes towards migrants as individuals and at the same time the cross-country variation in these personalized attitudes 
is higher than in generalized ones (where the attitudes are more uniform). Interesting might be also the finding that the difference between personalized and generalized attitudes towards migration seems to be greater in "traditional" immigration countries, which are (unlike the countries of CEE) particularly tolerant when it comes to immigrants as individuals but not that much when it comes to assessing the benefits and costs of immigration (i.e. higher mean differences between individual and group level attitudes are observed in the countries with more positive attitudes at an individual level).

\subsection{Factors that influence migration attitudes on personalized and generalized levels}

In the next step of our analysis we ran two separate OLS regressions for two dependent variables measuring personalized and generalized migration attitudes. In line with our research hypotheses we were interested in testing the effects of the same set of factors on our two newly constructed dependent variables, i.e. the influence of individual characteristics of respondents and contextual factors. We expected migration attitudes to be explained by a respondent's socio-demographic characteristics (age, gender and education), his or her socio-economic status (measured by experience of unemployment and self-evaluation of own income), the intensity of contacts with immigrants and the orientation toward the human values which we assume to be connected with migration attitudes (benevolence, universalism, traditionalism and security). In the regression analysis presented in Table 4 we used a dichotomous index for gender (male) and a continuous variable for age. Education was also dichotomized with a value of 1 for those with university education. When it comes to experience of unemployment ${ }^{9}$ we used two dichotomous variables: 1 ) experiencing unemployment for a period of between 3 and 12 months and 2) for a period of more than 12 months (no unemployment experience longer than 3 months was used as a reference group). Due to significant missing data on respondents' income we used the question concerning the subjective evaluation of income $\mathrm{e}^{10}$, which was also transformed into two dichotomous variables: (1) respondents coping on present income and (2) those who feel it is difficult or very difficult to cope on their present income (those who live comfortably on their present income were

9 Questions used: F 36 Have you ever been unemployed and seeking work for a period of more than three months? F37 Have any of these periods lasted for 12 months or more?

10

For feeling about the household's income nowadays, we used question F42 Which of the descriptions on this card comes closest to how you feel about your household's income nowadays? The respondents had to choose one answer: Living comfortably on present income, coping on present income, finding it difficult on present income, finding it very difficult on present income, don't know. 
used as a reference group). To measure the effect of the intensity of contacts with immigrants in our regression analyses we introduced three dichotomous indicators ${ }^{11}$ created from answers to two questions in ESS 7: (1) respondents who have close contacts with immigrants (close friends), (2) those with frequent contact (no close friends but contact with immigrants at least once a week, and (3) those with a few contacts (contacts with immigrants several time a month and less); while respondents with no personal contacts were used as a reference group.

In order to control for the effect of the human values we decided to also introduce four indexes for the values in our regression analyses. We selected the human values which we assume to have a positive (benevolence and universalism) or negative (traditionalism and security) effect on the migration attitudes we were measuring. The (centred) indexes for these human values were derived from the Portrait Values Questionnaire available in ESS 7 and constructed in line with Schwartz's (1992) guidelines.

Apart from the individual characteristics of respondents we also wanted to explore the effect of contextual indicators. The first indicator we used here was the share of non-citizens from Eurostat data ${ }^{12}$. By introducing our second contextual indicator into the model we aimed to control for the effect of the economic situation in given country. We are aware that GDP per capita might be not a straightforward indicator of economic success, so we do not expect that in countries with higher GDP (i.e. a better economic situation) there should necessarily be less competition for jobs, and significantly more tolerant attitudes towards immigrants. However, we decided to use this indicator as a control variable.

Based on the exploratory analyses described above, we decided to introduce an indicator for the migration situation in the country, which deserves more explanation here. Since our aim was to measure the effect of the stage of "migration maturity" of the country we decided to modify the typology proposed by Okolski (2012) and influenced by two basic concepts: "migration transition"13 and "migration cycle". The "migration cycle" involves three consecutive stages: the first when a country is overwhelmed by the outflow of its inhabitants and the proportion of foreign nationals in the total population continues to be marginal, the second when the migration transition takes place, and the third when immigration systematically predominates over emigration and foreigners constitute a considerable proportion of the population (Okolski 2012). The crucial factor for

11 We used question: D 19 Do you have any close friends who are of a different race or ethnic group from most [country] people? D20 How often do you have any contact with people who are of a different race or ethnic group from most [country] people when you are out and about?

12 http://ec.europa.eu/eurostat/data/database

13 The term "migration transition" is used to describe how migration status of individual European countries has transformed from emigration to immigration (Okolski 2012). 
Tab. 3 - Descriptive statistics of all variables included in the models

\begin{tabular}{|c|c|c|}
\hline Descriptive statistics for variables included in the models & $\%$ & Mean \\
\hline \multicolumn{3}{|l|}{ Dependent variables } \\
\hline Personalized attitudes - Social distance & & 7.08 \\
\hline Generalized attitudes - Group threat & & 4.77 \\
\hline \multicolumn{3}{|l|}{ Predicators } \\
\hline Male & 48.3 & \\
\hline Age & & 50.49 \\
\hline University educated & 23.7 & \\
\hline \multicolumn{3}{|l|}{ Experience with unemployment } \\
\hline Never unemployed more than 3 months & 71.4 & \\
\hline Unemployed for 3-12 months & 15.8 & \\
\hline Unemployed for more than 12 months & 12.8 & \\
\hline \multicolumn{3}{|l|}{ Subjective income evaluation } \\
\hline Living comfortably on present income & 35.2 & \\
\hline Coping on present income & 46.1 & \\
\hline Difficult and very difficult on present income & 18.6 & \\
\hline \multicolumn{3}{|l|}{ Contact with immigrants } \\
\hline No personal contacts at all & 11.6 & \\
\hline No close friends and only few personal contacts & 20.3 & \\
\hline No close friends but frequent personal contact & 19.6 & \\
\hline Close friends & 48.5 & \\
\hline \multicolumn{3}{|l|}{ Human values } \\
\hline Benevolence & & 0.74 \\
\hline Universalism & & 0.60 \\
\hline Security & & 0.38 \\
\hline Tradition & & 0.01 \\
\hline \multicolumn{3}{|l|}{ Country by type of immigration } \\
\hline "Old immigration countries" & 64.2 & \\
\hline "Future migration countries" (CEE countries) & 26.9 & \\
\hline "New migration countries" (Southern Europe) & 8.9 & \\
\hline
\end{tabular}

Notes: Mean values for dependent variables are on the scale from 0 to 10 , where 10 means most positive attitudes. Minimum Age of the respondents is 16 and maximum is 106. Indexes for the human values are calculated from the answers to the Portrait Values Questionnaire in ESS based on Schwarz's Basic Human Values; the higher the average, the greater is the inclination towards given value orientation.

sorting the countries into three groups was the time of change of the migration balance and the geographical location of the country. Following the logic of the proposed typology we divided the countries in our sample into three groups ${ }^{14}$ and

14 The typology originally included just 9 European countries. Among the "old" migration countries were Austria, France, the "new" migration countries were represented by Italy, Greece, Portugal and Spain, and a third group was created of Czechia, Hungary and Poland (Okolski 2012). 
introduced two dichotomous indicators in the regression: (1) countries of CEE or "future migration countries" (Czechia, Estonia, Hungary, Lithuania, Poland, and Slovenia), (2) countries of Southern Europe or "new migration countries" (Spain and Portugal), while all the rest of the European countries in the data were described "as old migration countries" and were treated as a reference group.

Descriptive statistics of all variables included in the models are are summarized in the Table 3.

\subsection{Results and discussion}

In the next step of the analysis we ran a set of OLS regressions on two separate dependent variables, which stand for personalized attitudes towards immigrants (Social distance) and generalized attitudes towards immigration as a phenomenon (Group threat). We introduced predicting factors in three steps: (1) sociodemographic characteristics, socio-economic status and the intensity of contacts with immigrants; (2) all variables mentioned in the first step plus four human value indicators; (3) all the mentioned individual characteristics plus contextual indicators. A comparison of the fit coefficients for nested and full models proved that the complex regression model with all the predictors described above had a better fit on both levels. Therefore here we illustrate and interpret the more complex models including all predicators described above (see Table 4).

The regression analysis illustrated in Table 4 showed that university education is positively and significantly correlated with migration attitudes on both levels. Respondents with university education tend to express significantly more positive views when it comes to accepting individual migrants in closer personal contacts and to judging the influence of migration on the whole society (here the effect of university education is even greater). The effect of other socio-economic variables is not so straightforward. Analysis suggests that greater satisfaction with income is associated with more tolerant attitudes on both levels. Those who claimed that they are coping with (great) difficulty on their present income are especially sceptical when it comes to assessing the outcomes of migration as a phenomenon. At the same time, having experience of unemployment seem to have no statistically significant effect (slightly positive but not significant) on the individual level of attitudes, although it had a significant and slightly negative effect on a generalized level. ESS data seem to partially confirm our hypotheses saying that (H3) higher education and higher socio-economic status have a positive impact on migration attitudes on both levels and that (H3A) experience of socio-economic hardships has a stronger negative effect on attitudes towards migration as a phenomenon (compared to personalized attitudes towards immigrants). We suggest that the described (slight positive or none) effect on social distancing could be a result of 
Tab. 4 - Factors influencing personalized and generalized migration attitudes

\begin{tabular}{|c|c|c|c|c|}
\hline \multirow{2}{*}{ Individual characteristics } & \multicolumn{2}{|c|}{$\begin{array}{c}\text { Personalized attitudes } \\
\text { Social distance } \\
\text { B (Sig.) }\end{array}$} & \multicolumn{2}{|c|}{$\begin{array}{c}\text { Generalized attitudes } \\
\text { Group threat } \\
\text { B (Sig.) }\end{array}$} \\
\hline & & & & \\
\hline Sex (male) & -.052 & & .072 & $* * *$ \\
\hline Age & -.024 & $* * *$ & -.003 & $* * *$ \\
\hline University education & .390 & *** & .601 & *** \\
\hline \multicolumn{5}{|l|}{$\begin{array}{l}\text { Experience with unemployment } \\
\text { (never longer than } 3 \text { months as a reference group) }\end{array}$} \\
\hline Unemployed for $3-12$ months & .031 & & -.095 & $* * *$ \\
\hline Unemployed for more than 12 months & .040 & & -.175 & $* * *$ \\
\hline \multicolumn{5}{|l|}{$\begin{array}{l}\text { Subjective income evaluation } \\
\text { (living comfortably as a reference group) }\end{array}$} \\
\hline Coping on present income & -.238 & *** & -.232 & $* * *$ \\
\hline Difficult and very difficult on present income & -.471 & $* * *$ & -.699 & $* * *$ \\
\hline \multicolumn{5}{|l|}{$\begin{array}{l}\text { Contacts with immigrants } \\
\text { (no personal contacts at all as a reference group) }\end{array}$} \\
\hline Close friends & 1.056 & $* * *$ & .463 & $* * *$ \\
\hline No close friends but frequent personal contact & .296 & $* * *$ & .060 & \\
\hline No close friends and only few personal contacts & .154 & *** & .203 & $* * *$ \\
\hline \multicolumn{5}{|l|}{ Human values } \\
\hline Benevolence & .206 & $* * *$ & -.010 & \\
\hline Universalism & .957 & *** & .665 & $* * *$ \\
\hline Security & -.145 & $* * *$ & -.265 & $* * *$ \\
\hline Tradition & -.185 & $* * *$ & -.098 & $* * *$ \\
\hline \multicolumn{5}{|l|}{ Contextual (country) effects } \\
\hline Share of non-citizens in the country & -.044 & *** & .014 & *** \\
\hline GDP per capita & .000 & *** & .000 & \\
\hline \multicolumn{5}{|l|}{$\begin{array}{l}\text { Country by type of immigration } \\
\text { ("old immigration countries" as a reference group) }\end{array}$} \\
\hline "Future immigration countries" (CEE countries) & -.810 & *** & .067 & * \\
\hline "New immigration countries" (South European Countries) & .427 & $* * *$ & .018 & \\
\hline R Square of the model & \multicolumn{2}{|c|}{0.237} & \multicolumn{2}{|c|}{0.209} \\
\hline
\end{tabular}

Source: ESS 7; $N=23,486$.

Note: Results of OLS regression for dependent variables with 11 items scale (10 most positive).

Significance at ${ }^{*} p<0.1$, ${ }^{* *} p<0.05$, and ${ }^{* * *} p<0.01$.

the fact that certain immigrants are clustered on the lower rungs of the labour market and therefore respondents with lower socio-economic status are likely to have more personal interactions with immigrants through their work experience.

When it comes to testing the contact hypotheses, regression analysis showed that personal experience with immigrants is a strong predicator of positive migration attitudes on both levels studied. Results seem to support our fourth hypothesis; although it is not very clear whether we can claim that the effect of personal 
contacts with immigrants is much higher when it comes to attitudes towards immigrants as individuals compared to generalized attitudes (H4A). ESS data suggest that even having a few personal contacts with immigrants significantly increases the score of respondents on both attitudinal scales ${ }^{15}$ and the effect is even slightly higher for generalized attitudes. At the same time, having migrants as close friends particularly improves what we call personalized attitudes. According to our tested models respondents with no personal contacts with immigrants will score more than one point worse on the social distance scale compared to those who have close friends among immigrants (given that they have the same socio-demographic characteristics, socioeconomic status, and values, and they are living in the same country).

The results of the regression analysis presented in Table 4 suggest that human values should also be taken into account when predicting migration attitudes; though our fifth hypothesis was only partially confirmed. Among the tested human values, universalism, traditionalism and security all have a significant effect on both attitudinal levels studied here. Respondents inclining towards understanding, appreciation, tolerance, and protection for the welfare of all people (universalism values) tend to have significantly more tolerant attitudes towards migrants as individuals and also towards migration as a phenomenon (although here the effect is slightly less). On the contrary, those who are more oriented toward conservative values such as safety, harmony, stability of society and relationships, and stability of their own status (security values), as well as respect, commitment, acceptance of the customs and ideas of their own culture or religion (traditionalism), will express rather reserved feelings towards both immigrants as individuals and immigration as a phenomenon. The only tested human value which seems to have a different effect on the attitudinal levels studied is benevolence. This self-transcendent human value oriented towards preserving and enhancing the welfare of others and to people with whom one is in frequent personal contact (friends) seems to be positively related only to personalized attitudes towards immigrants but to have no significant effect on judging the outcomes of immigration as a phenomenon.

Our last tested set of hypotheses deals with the effect of contextual indicators. Analysis of ESS data suggests that the national context might in fact have a strong effect on migration attitudes even when controlling for the effect of individual characteristics of respondents, such as educational level, socioeconomic status, human values and also personal contacts with immigrants. We were not particularly interested in interpreting the effect of GDP per capita on migration attitudes but in one of our models it has a slight positive impact and it seems to

15 Compared to those respondents who have no personal contacts with immigrants at all. 
be a good idea to control for the effect of this economic predictor when discussing other important factors. Similarly, we did not intend to test the effect of the share of immigrants on migration attitudes but regression results brought rather unexpected findings. According to our models, the share of foreign citizens in the country seems to have significant but contradictory effects on the studied levels: slightly positive on generalized attitudes (reducing the social threat) and slightly negative on personalized attitudes (increasing social distance). Being aware of the nature of the indicator used (i.e. the share of foreign citizens and not foreignborn or migrant-background population), at this point we prefer to avoid further interpretations and do not want to draw any misleading conclusions. The effect of the share of immigrants in the country on immigration attitudes in the two dimensions we extracted deserves further in-depth research and the elaboration of specific research arguments.

What we were especially interested to test was the effect of the migration context in the country, based on the typology of "migration maturity" proposed by Okolski (2012). The exploratory analysis described in the previous part of the article suggests that the difference between personalized and generalized attitudes towards migrants has a similar nature across the countries, i.e. attitudes towards immigrants as individuals generally tend to be more positive. At the same time we also found that the difference between the two measured attitudinal indexes varies substantially across the countries. Explorative analysis suggests that the cross-country variation is bigger when it comes to personalized attitudes towards migrants, which seem to be considerably more positive in countries with a relatively longer history of immigration. Regression analyses produced an interesting elaboration to mentioned findings. The coefficients presented in Table 4 suggest that respondents living in CEE countries ("future migration countries") seem to be significantly more sceptical when it comes to personalized attitudes towards immigrants. Respondents in this group of countries on average score almost one point worse than people in "old immigration countries" (given that they have the same individual characteristics and the same personal experience with immigrants). On the contrary, respondents in South European countries ("new migration countries") seem to express the most tolerant views when it comes to social distancing from migrants. This finding could probably be attributed to the fact that many people in these countries have immigration experience themselves and as previous studies suggest immigration experience makes people more tolerant towards immigrants (Citrin et al. 1997).

Therefore, the difference in social distancing is not fully explained by personal characteristics of the respondents, their economic situation, human values, the number of immigrants in the country and even personal contacts with those immigrants. ESS data suggest that country context does matter here. On the contrary, when it comes to judging the benefits from migration, the typology of migration 
maturity proposed here produced rather unexpected results. While attitudes towards migration as a social phenomenon in "old immigration countries" turned out to be similar to those in "new migration countries" (the difference is not statistically significant), respondents in "future migration countries" turned out to be slightly more positive when judging the benefits of migration (see the positive and significant coefficient next to the CEE variable in the model for the group attitudes). While interpreting this finding one should take into account the differences of attitudes across CEE countries. According to Okolski's typology Poland belongs to so called "future migration countries" of CEE which all have certain similarities when it comes to migration history, migration context and practices and most importantly when it comes to "the "maturity" of migration policies as such. But in fact many previous studies already noted that in terms of attitudes towards immigrants Poland is rather an outlier in the group and in the region (Meuleman, Davidov, Billiet 2009; Leontiyeva 2015). The special position of Poland is also obvious in Figure 1. The attitudes of Polish respondents are in fact above the average for Europe and they obviously influence the score for the group significantly ${ }^{16}$. Mentioned typology could be also problematic for Czechia, which does belong to the CEE region but according to some authors the country is also an outlier in the region with relatively more developed immigration policies and larger immigration flows (Drbohlav 2011). Therefore, for the purpose of future research, the typology proposed here should be further refined.

\section{Conclusions and questions for further research}

In the light of the growing number of refugees in Europe and the risk of rising anti-migration sentiments connected to the perceived threat for host societies, research into attitudes towards immigration seems very relevant. We hope that our analysis has contributed to the scholarly debate about the formation of migration attitudes and the factors that influence them. Our aim was to show that it makes sense to differentiate between personalized and generalized dimensions of migration attitudes. We argue that, even though personalized and generalized attitudes are correlated, one person may in fact have rather positive attitudes towards individual immigrants (in terms of willingness to accept them in closer contacts in everyday life) and at the same time express reservations about immigration as a phenomenon (be more sceptical about the positive outcomes of international migration). To simplify, the attitude "I do not mind migrants; it is migration that bothers me" does not necessarily mean an inconsistency of beliefs.

16 In addition, in ESS 7 we lacked data for Slovakia, another "future migration country" in the region with rather reserved attitudes towards migrants, similar to Czechia. 
The regression analysis presented in this article suggests that the socioeconomic status of respondents has more influence on generalized attitudes towards the phenomenon, while having close contacts with immigrants (especially having close friends) tends to have a greater effect on willingness to accept individual migrants. Of course, in further research it would be appropriate to use more indicators for personalized attitudes (not only the two available from the ESS 7 data). We hope that despite certain data limitations our analysis has provided enough arguments to suggest that the mechanisms for the formation of personalized and generalized migration attitudes might be different. We partially proved both theoretical concepts which stand behind our studied levels. The ethnic group threat (generalized level) is primarily influenced by the worse economic status of an individual, but not that much the size of the migration population. The attitudes towards migrants as individuals (measured by the concept of social distance) are primarily formed by having or not having personal contacts with migrants.

Last but not least, our analysis was intended to contribute to the discussion about the importance of the country context for migration attitudes. Regression analysis suggests that when talking about migration attitudes country context matters significantly, even when controlled for the effect of respondents' educational level, their socioeconomic status, human values and personal contacts with immigrants. In our analysis we found a significant cross-country variation in personalized attitudes towards immigrants (social distancing) and a strong effect of personal contacts with immigrants on these attitudes. These findings could be attributed to both lack of experience with immigrants in "future migration countries" (CEE) and social desirability in countries with a relatively longer experience of immigration. On one hand, Europeans in "old immigration countries" (as well as Southern European countries) may in fact experience less discomfort during personal encounters with immigrants since their society is more diverse. On the other hand, expressing personalized negative attitudes towards immigrants is more likely to be socially unacceptable in such countries when compared to CEE countries where the experience with immigration is relatively recent and the immigration discourse as such is relatively new. Therefore, the difference in assessing the effect of immigration on a host society in for example Czechia and the United Kingdom may not be so great (3.62 versus 4.4 on a scale from 0 to 10) but the difference between personalized attitudes in terms of willingness to accept mixed marriages with migrants or having a migrant as a boss is really high (4.61 versus 7.47). In fact, Czechia scored as the least tolerant country in the ESS 7 sample and attitudes towards immigrants as individuals and immigration as a phenomenon in this country turned out to be even more sceptical than in Hungary. Taking into account the recent influx of immigrants in Southern Europe and the unacceptable situation of refugees in countries like Greece and Italy, it would 
be also more than desirable to include the attitudinal data from these countries in further cross-country comparison $\mathrm{s}^{17}$ and also to try using more sophisticated contextual indicators such as the content and the quality of political and media discourse concerning migration.

\section{References}

ANÝŽOVÁ, P. (2014): Srovnatelnost Schwartzovy hodnotové škály v mezinárodních datech. Czech Sociological Review, 50, 4, 547-581.

BOBO, L., HUTCHINGS, V.L. (1996): Perceptions of racial group competition: Extending Blumerss theory of group position to a multiracial social context. American Sociological Review, 61, 6, 951-972.

BREWER, M.B., MILLER, N. (1984): Beyond the contact hypothesis: Theoretical perspectives on desegregation. In: Miller, N., Brewer, M.B. (eds.): Groups in contact: The psychology of desegregation, Academic Press, Orlando, 281-302.

DAVIDOV, E. (2008): A cross-country and cross-time comparison of the human values measurements with the second round of the European Social Survey. Survey Research Methods, 2, $1,33-46$.

DIXON, J.C. (2006): The Ties That Bind and Those That Donst: Toward Reconciling Group Threat and Contact Theories of Prejudice. Social Forces, 84, 4, 2179-2204.

DRBOHLAV, D. (2011): Imigrace a integrace cizinců v Česku: Několik zastavení na cestě země v její migrační proměně z Davida na téměř Goliáše. Geografie, 116, 4, 401-421.

CITRIN, J., GREEN, D. P., MUSTE, C., WONG, C. (1997): Public Opinion toward Immigration Reform the Role of Economic Motivations. The Journal of Politics, 59, 3, 858-881.

COENDERS, M., SCHEEPERS, P. (2003): The effect of education on nationalism and ethnic exclusionism: an international comparison. Political Psychology, 24, 2, 313-343.

FACCHINI, C., MAYDA, A.M. (2006): Individual Attitudes towards Immigrants: Welfare-State Determinants across Countries. IZA Discussion Paper 2127. Bonn: Institute for the Study of Labor (IZA).

FORBES, H.D. (2004): Ethnic Conflict: Commerce, Culture, and the Contact Hypothesis. Yale University Press.

HAINMUELLER, J., HISCOX, M.J. (2007): Educated preferences: Explaining attitudes toward immigration in Europe. International organization, 61, 2, 399-442.

HECKMANN, F., SCHNAPPER, D. (2003): The Integration of Immigrants in European Societies: national differences and trends of convergence. Lucius \& Lucius, Stuttgart.

INGLEHART, R., WELZEL, C. (2005): Modernization, cultural change, and democracy: The human development sequence. Cambridge University Press.

ISLAM, M.R., HEWSTONE, M. (1993): Dimensions of contact as predictors of intergroup anxiety, perceived out-group variability, and out-group attitude: An integrative model. Personality and Social Psychology Bulletin 19, 6, 700-710.

LEONTIYEVA, Y. (2015): Postoje k migrantům v zemích Visegradské čtyřky: proměny v čase a kontexuální vlivy. In: Vlachová, K. (ed.): Národní identity a identifikace, SLON, Praha, 143-156.

${ }^{17}$ In the ESS 7 module the data for these countries was lacking. 
MAYDA, A.M. (2004): Who is Against Immigration? A Cross-Country Investigation of Individual Attitudes toward Immigrants. IZA Discussion Paper 1115, IZA, Bonn.

MEULEMAN, B.E. DAVIDOV, J., BILLIET (2009): Changing attitudes toward immigration in Europe, 2002-2007: A dynamic group conflict theory approach. Social Science Research, $38,2,352-365$.

OKÓLSKI, M. (2012): Transition from emigration to immigration: Is it a destiny of modern European countries. In: Europe, The continent of immigrants. Trends, structures and policy implications, IMISCOE Research Series, Amsterdam University Press, 10-27.

OUELLETTE-KUNTZ, H., BURGE, P., BROWN, H.K., ARSENAULT, E. (2010): Public attitudes towards individuals with intellectual disabilities as measured by the concept of social distance. Journal of Applied Research in Intellectual Disabilities, 23, 2, 132-142.

PETTIGREW, T.F. (1979): The ultimate attribution error: Extending Allport's cognitive analysis of prejudice. Personality and social psychology bulletin, 5,4, 461-476.

PETTIGREW, T.F. (1998): Intergroup contact theory. Annual review of psychology, 49, 1, 65-85.

PETTIGREW, T.F., TROPP, L.R. (2006): A meta-analytic test of intergroup contact theory. Journal of personality and social psychology, 90, 5, 751-783.

PETTIGREW, T.F., TROPP, L.R., WAGNER, U., CHRIST, O. (2011): Recent advances in intergroup contact theory. International Journal of Intercultural Relations, 35, 3, 271-280.

SCHNEIDER, S.L. (2008): Anti-immigrant attitudes in Europe: outgroup size and perceived ethnic threat. European Sociological Review 24,1, 53-67.

QUILLIAN, L. (1995): Prejudice as a Response to Perceived Group Threat: Population Composition and Anti-Immigrant and Racial Prejudice in Europe. American Sociological Review, 60, 4, 586-611.

QUILLIAN, L. (1996): Group threat and regional change in attitudes toward African-Americans. American Journal of Sociology, 102, 3, 816-860.

RAIJMAN, R., SEMYONOV, M. (2004): Perceived threat and exclusionary attitudes towards foreign workers in Israel. Ethnic and Racial Studies, 27, 5, 780-799.

SAVELKOUL, M., SCHEEPERS, P., TOLSMA, J., HAGENDOORN, L. (2010): Anti-Muslim attitudes in the Netherlands: Tests of contradictory hypotheses derived from ethnic competition theory and intergroup contact theory. European Sociological Review, 27, 6, 741-758.

SEMYONOV, M., RAIJMAN, R., TOV, A.Y., SCHMIDT, P. (2004): Population size, perceived threat, and exclusion: A multiple-indicators analysis of attitudes toward foreigners in Germany. Social Science Research, 33, 4, 681-701.

SCHEEPERS, P., GIJSBERTS, M., COENDERS, M. (2002): Ethnic exclusionism in European countries. Public opposition to civil rights for legal migrants as a response to perceived ethnic threat. European sociological review, 18, 1, 17-34.

SCHLUETER, E., SCHEEPERS, P. (2010): The relationship between outgroup size and antioutgroup attitudes: A theoretical synthesis and empirical test of group threat-and intergroup contact theory. Social Science Research, 39, 2, 285-295.

SCHLUETER, E., WAGNER, U. (2008): Regional differences matter examining the dual influence of the regional size of the immigrant population on derogation of immigrants in Europe. International Journal of Comparative Sociology, 49, 2-3, 153-173.

STRABAC, Z., AALBERG, T., VALENTA, M. (2014): Attitudes towards Muslim immigrants: evidence from survey experiments across four countries. Journal of Ethnic and Migration Studies, 40, 1, 100-118.

STRABAC, Z., LISTHAUG, O. (2008): Anti-Muslim prejudice in Europe: A multilevel analysis of survey data from 30 countries. Social Science Research, 37, 1, 268-286. 
SCHWARTZ, S.H. (1992): Universals in the content and structure of values: Theoretical advances and empirical tests in 20 countries. Advances in experimental social psychology, 25, 1-65.

VLACHOVÁ, K. (2017): Significant others and the importance of ancestry for Czech national identity. National Identities, http://www.tandfonline.com/doi/full/10.1080/14608944.2017. 1362378 (1.9.2017).

WAGNER, U., CHRIST, O., PETTIGREW, T.F., STELLMACHER, J., WOLF, C. (2006): Prejudice and minority proportion: Contact instead of threat effects. Social psychology quarterly, 69, 4, 380-390.

WANG, B., COLLINS, F.L. (2016): Emotions and cosmopolitan sociability: Barriers and opportunities for intercultural encounters amongst new Chinese migrants in New Zealand. Journal of Ethnic and Migration Studies. 42, 1, 88-102.

WARK, C., GALLIHER, J.F. (2007): Emory Bogardus and the origins of the social distance scale. The American Sociologist, 38, 4, 383-395.

WILKES, R., GUPPY, N., FARRIS, L. (2008): No Thanks, We're Full: Individual Characteristics, National Context, and Changing Attitudes Toward Immigration. International Migration Review, 42, 2, 302-329.

ZICH, F., ANÝŽOVÁ, P., eds. (2016): Konfrontace hodnot v pozdní modernitě: Česko a Hlučínsko v evropském kontextu, SLON. Praha.

\section{SHRNUTí}

\section{„Nemám nic proti imigrantům, ale imigrace mi vadí.” Nejednotnost v postojích $k$ imigraci v Evropě}

Článek byl inspirován probíhající debatou v mnoha zemích EU o tzv. „migrační krizi“. Tato diskuse osciluje mezi dvěma rovinami: (1) být humánní vůči lidem v nouzi (rovina individuální) a (2) právo státu chránit blahobyt přijímající společnosti, kulturního dědictví, demokratických hodnot atd. (rovina celospolečenská). Naším cílem je studovat rozdílné postoje evropské populace v těchto dvou rovinách, tedy postoje vůči jednotlivým migrantům a postoje k mezinárodní migraci jako společenskému fenoménu. Dalším cílem nalézt faktory, které tyto postoje ovlivňují. Předpokládáme, že člověk může vyjadřovat své postoje k jednotlivým migrantům a k mezinárodní migraci jako společenskému jevu odlišně.

V naší analýze a interpretacích jsme využili především dva teoretické př́istupy $\mathrm{k}$ postojům k migrantům/migraci: koncept sociální vzdálenosti (concept of social distance) a teorii mezietnického soutěžení (interethnic competition theory). Koncepce sociální vzdálenosti měří, jak jsou jednotlivci ochotní se v různých oblastech (např. bydlení, smíšené manželství, na pracovišti) přiblížit lidem jiného etnického původu (Wark, Galliher 2007). Tento koncept je více zaměřen na osobní kontakty, vazby a vzájemné vztahy mezi jednotlivci, než na sebeidentifikaci se svou vlastní skupinou. Naopak teorie mezietnické soutěže je založen na sebeidentifikaci se s vlastní skupinou a identifikaci jiné skupiny („my“ versus „migranti“). Teorie vysvětluje negativní postoje k migrantům bojem o zdroje, a to jak hmotné (sociální dávky, bydlení, prostor), tak nehmotné jako je např. politická moc, hodnoty. Podle této teorie platí, že čím vyšší míra přistěhovalectví, tím vyšší hrozba z migrace (Dixon 2006). Vedle těchto dvou konceptů pracujeme s kontaktní teorií (contact theory), která zdůrazňuje pozitivní vliv mezilidských kontaktů s migranty na migrační postoje (Pettigrew 1998). 
Naší hlavní hypotézou je, že existují rozdíly v postojích v tom, jsou-li vyjadřované k jednotlivým migrantům či k migraci jako společenskému fenoménu. Dále předpokládáme, že postoje k jednotlivcům jsou pozitivnější než postoje k migraci jako fenoménu. Další hypotézy se týkaly vlivu dalších faktorů na postoje, a to na jednu či obě sledované roviny. Např́klad očekáváme, že respondenti se socioekonomickými problémy a hodnotami založenými na tradici a bezpečnosti, budou mít silnější vliv na postoje k migraci jako fenoménu. Naopak hodnoty universalismu a benevolence budou mít větší vliv na osobní rovinu postojů. Na obě roviny bude mít vliv vzdělání a dále kvalita a intenzita osobních kontaktů. Naše data pocházejí z Evropského sociálního výzkumu (ESS), ze sedmého vlny ESS realizované ve dvaceti evropských zemích v letech 2014-2015.

Zjistili jsme, že ve všech sledovaných zemích jsou rozdíly mezi postoji k migrantům jako jednotlivcům a migraci jako fenoménu statisticky významné (kromě Izraele), avšak rozdíl mezi měřenými indexy se v jednotlivých zemích liší. Respondenti ve všech zemích Evropy mají tendenci být pozitivnější, pokud jde o jejich postoje k migrantům jako jednotlivcům. Zajímavé je také zjištění, že rozdíl mezi sledovanými rovinami postojů jsou vyšší ve „starých“ přistěhovaleckých zemích, kde jsou migranti jako jednotlivci tolerantněji přijímáni a je k nim nižší sociální odstup. Postoje vypovídající o migraci jako hrozbě jsou v rámci Evropy téměř podobné. Nejnižší průměry obou konstruovaných ukazatelů byly nalezeny v českých a mad'arských datech, naopak respondenti ve Švédsku zaznamenali nejvyšší toleranci na obou úrovních. Regresní analýzy potvrdily, že respondenti s vysokoškolským vzděláním, vyjadřující větší spokojenost s příjmy, mají tendenci vyjádřit výrazně pozitivnější názory, pokud jde o přijímání jednotlivých migrantů do užších osobních vztahů a rovněž i v posouzení vlivu migrace na celou společnost. Rovněž respondenti, kteří chtějí pochopit, ocenit, tolerovat, chránit blaho všech lidí (hodnoty univerzalismu), mají tendenci mít značně tolerantnější postoje vůči migrantům jako jednotlivcům a také k migraci jako fenoménu, i když v druhém případě o něco méně. Pokud jde o testování kontaktní hypotézy, tak regresní analýzy ukázaly, že osobní zkušenost s migranty je silným predikátorem pozitivních postojů k migraci na obou studovaných úrovních.

Důležitým sdělením článku je, že táž osoba, která má spíše pozitivní postoje vưči jednotlivým migrantům ( $\mathrm{z}$ hlediska ochoty přijmout je v užších kontaktech v každodenním životě), může současně vyjádřit své výhrady k migraci jako celospolečenskému jevu.

Obr. 1 Průměr postojových indexů v jednotlivých zemích 